University for Business and Technology in Kosovo

UBT Knowledge Center

Oct 28th, 9:00 AM - Oct 30th, 5:00 PM

\title{
Legislative framework conflicts and their impact in generating the phenomena of coastalization in Albania
}

Doriana Musaj

Polytechnic University of Tirana, dori.musai@gmail.com

Follow this and additional works at: https://knowledgecenter.ubt-uni.net/conference

Part of the Architecture Commons

\section{Recommended Citation}

Musaj, Doriana, "Legislative framework conflicts and their impact in generating the phenomena of coastalization in Albania" (2016). UBT International Conference. 67.

https://knowledgecenter.ubt-uni.net/conference/2016/all-events/67

This Event is brought to you for free and open access by the Publication and Journals at UBT Knowledge Center. It has been accepted for inclusion in UBT International Conference by an authorized administrator of UBT Knowledge Center. For more information, please contact knowledge.center@ubt-uni.net. 
Legislative framework conflicts and their impact in generating the phenomena of coastalization in Albania

\title{
Legislative framework conflicts and their impact in generating the phenomena of coastalization in Albania
}

\author{
Doriana Musaj \\ Polytechnic University of Tirana \\ Department of Urbanism, Faculty of Architecture and Urbanism \\ dori.musai@gmail.com
}

\begin{abstract}
This paper argues about the legislative and institutional overlapping in managing the territory of Golem area (and country level) and the consequences that these conflicts have in generating the coastalization phenomena.

This research seeks to discover the relationship between land tenure systems, urban planning, sustainable tourism in terms of legislative framework and policies. In order to understand the past, to approach the present and to plan the future development of sustainable tourism in the coastal areas Failure to clarify the ownership of securities, non-implementation of planning instruments or territory management, non-implementation of property laws etc. has bring consequences in the territory in the form of whole quarters informal settlements or illegal, thus increasing the number of buildings and the loss of green territories along the coast. This growth has created cities that are populated only seasonally during the summer and who are abandoned during the fall and winter.
\end{abstract}

Keywords: Legislation Framework, Land ownership, Illegal/ Informal constructions, Tourism Strategies, Coastalization, Tourism Development

\section{Introduction}

This paper is built on three main pillars as the components of the spatial development in Albania. According to Bertaud (2006), Urbanization in Albania has gone through three distinct phases since the fall of communism:

The first phase (1991-1997) was dominated by the informal market. The phenomena of internal migration from the eastern rural areas of the country in the western urban areas or in the coastal zone dominated. At the initial stage, most informal settlers' building activity was in, or around the main city and settlements was only used for housing purposes. The vacuum created by the collapse of the regime in ' 90 , in the uncertainly land tenure and the legal framework, made it easier to claim a lot of vacant land in the periphery of the city.

The second phase (1998-2006) saw the consolidation of the informal sector and the partial regularization of the informal sector. The municipalities started to be better organized. This phase saw the emergence of a formal real estate sector. New professions were created such as real estate brokers, 
Book of Proceedings

International Conference on Architecture and Spatial Planning

developers, entrepreneurs who did not exist before. But this phase mostly developed in the cities where the land re-developed by obsolete buildings.

The third phase (2006- present) consists in the consolidation of the formal sector and the regularization of the informal sector. The third phase of urbanization consists on developing laws and regulations and enforcing them so that real-estate market will become entirely formal. The new neighborhoods created informally during the beginnings of 90' (the first phase of urbanization in Albania, still today form an important part of the existing housing stock. At around 2006 a new dynamic formal housing sector emerged. Even though has passed 15 years the new developers, formal one, faced the same problem.

\section{Research and Assessment of the Topic}

Literature Review about the topic used to assess the measurements of the problem addressed is:

- Legislation framework. Balkan countries in the begging of 90-s; Land tenure during communism regime; Land reform in the 1990s; Local government and spatial planning; Legal framework on spatial and urban planning;

- Land tenure and property rights. Property rights; Tenure security and regularization; Land fragmentation;

- Informal market. Informal settlements in Balkan; Vienna Declaration on National and Regional Policy Programs; Informal structure intervention

- Urban Development. Urbanization framework Theories/Concepts; Urban development in Albania; Urban planning legislation framework. Tourism development.

\section{Study case. Golem area , Kavaja}

\subsection{Legislative framework on land management}

On 19.7.1991 was approved Law no. 7501, "On Land", which authorized the sharing and transfer of land to collective farms, family members in parts of equal. This is a very important moment in Albanian land tenure history, because this was the second agrarian reform after the 1945, which distributed land by using the principle of equality and without taking in view the interests of the former owners, who were expropriated by the first one.

So, in determining land ownership and use rights, the law "On Land" does not recognize land ownership, size and margins, which were before collectivization carried out under the previous regime. One other very important law concerning the ownership is Law No. 7698 in 1993 "On compensation the value of agricultural land to former owners." Based on this Law: "... when return properties is not possible, the state will compensate the former owners for loss of property, through financial compensation, or land equivalent government bonds, former owners can be compensated with the distribution of agricultural land still from the state or land rights in developing potential tourist areas..." The program of Compensation and Restitution of former owners, whose property was expropriated during the communist regime, was consolidated by law 2 years after the privatization and the farmland distribution program was implemented and acted. This time-space caused the first conflicts between new owners (those who gained rights under the post-1991 privatization legislation) and former owners, conflicts that over time caused major legal and technical problems. 
Legislative framework conflicts and their impact in generating the phenomena of coastalization in Albania

Despite legal, land tenure problems a significant issue that accompanies us nowadays is the physical division. In Albanian institutional and legal history, this is one of the most challenged laws.

Fig. 1 Aerial photography

Subdivision of the agricultural land according to law 7501

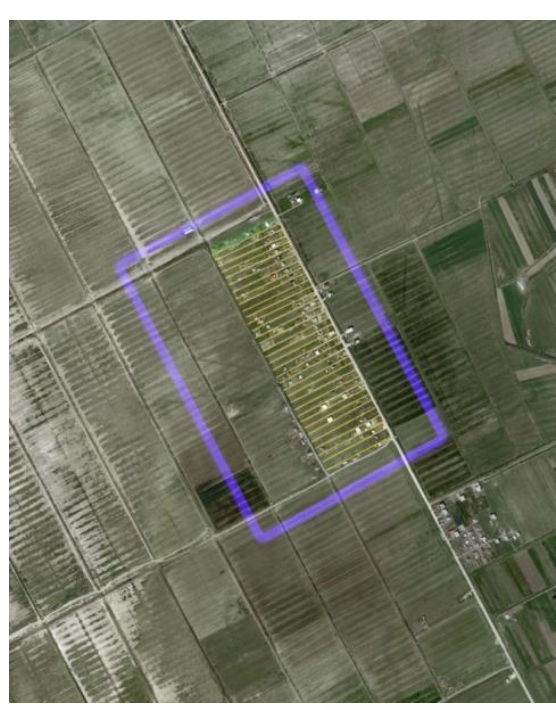

Fig.2 Subdivision of one plot into "dynym per fryme"47

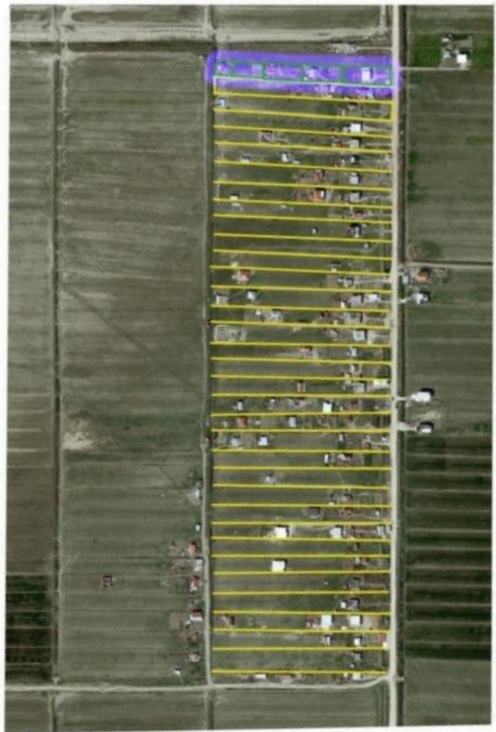

Fig.3 Subdivision of one plot into several parts possessed by several owners

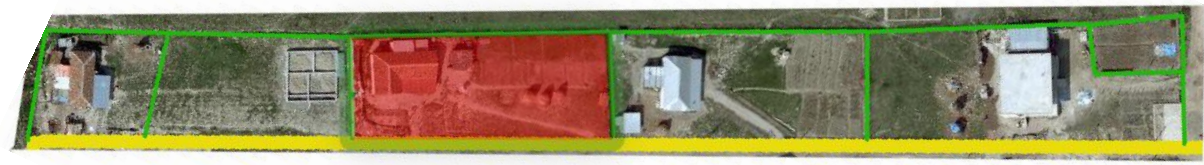

\subsection{The illegal consequences and Informal market}

What complicated the situation was the subdivision informally of the land. The owners that gained the land through the law 7501, later on, sold part of that land to new owners, in many cases without legal documents. As shown by the fig no.4 one plot is separated to more than two owners, and both of them

${ }_{47}$ "Dynym per fryme" is the division of the agricultural land according to law 7501 
Book of Proceedings
International Conference on Architecture and Spatial Planning

have built houses mostly illegally. Here there is a double problem, the first on clarification of the land tenure (who owns legally, whose not) and second the illegal buildings. In different cases, according to Aluizni records, neither the peasant of the house nor the peasant of the land has legal documents.

As Andoni emphasizes in her paper, Albanian informal settlement from the beginning (in the 90-s) until now have created neighborhoods attached to the city, becoming part of it. So all definition created from over the world to identify informal or/and illegal houses as "spread city", divided city", "irregular houses", illegal settlements", "informal development", etc., can and may fit in Albanian case.

According to Aliaj, 6-7 from 10 buildings (from 1990-2000) are built informally or illegally. In "Albania it is assumed that there are approx. 6-8 billion USD invested in informal settlements referring to the De Soto term "dead capital" and that some 40000 hectares land is occupied in either illegal or informal way" Andoni (2007)

In these circumstances in April 2006 the parliament approved law no.9482 "On legalization, urbanization and integration of informal constructions" and therefore established ALUIZNI, which was a government agency with the main purpose to collect data from the field and to finalize the legalization of all informal buildings.

\subsection{Urban development \& Urban planning legislation}

In 1998 the parliament approved the first law on the urban planning Law no. 8405, date 17.9.1998 "On City planning". The law consists in regulating through a certain rules and methods the urban area.

The latest one approved by the Albanian Parliament, is dated on 23.4.2009, no. 10119, "For urban planning" and all its integral regulations. After that different amendments have been added or even changed. This law is to define the basic principles, responsibilities, rules and procedures for planning. The purpose of this law differs from the Law no. 8405, date 17.9.1998 "For urban Planning" is the target and aims:

a) Ensure sustainable development of the territory, through the rational use of land and natural resources;

b) Assess current and future potential for development of the territory at the national and local level, based on the balancing of natural resources, the human and economic needs of public and private interests by coordinating:

c) Enable the use of the right of property development, in accordance with environmental laws and planning instruments;

d) Create appropriate conditions of equal rights and opportunities for housing, economic and social activities for all social, economic and social cohesion and joy of property rights;

e) Ensure that national and local authorities to develop plans and regularly update the planning instruments, according to market demands and social needs;

f) Ensure that planning authorities coordinate their planning activities, to promote the harmonious planning of integrated territory; ..etc.

\subsection{Touristic areas and Tourism development}

The first document related to tourism development in Albania after communism has fallen, is for certainly the law no.7665 date 21.1.1993 “On the development of priority touristic zones". This Law used to stimulate tourism development by promoting new touristic areas to be developed as hotels and villages. The law introduces new concepts such as: Incentive Person (IP) title, Incentive areas and Incentive activity. Data collected from ministry, shows 52 IP persons/legal entity gained the title and 
Legislative framework conflicts and their impact in generating the phenomena of coastalization in Albania

signed the agreements (development and/or rental). Around 15 of them didn't develop the plan or developed only partly.

At the begging of 2005, the government then took a decision to suspend new rental and development assignment contracts, with the justification to clarify land ownership titles and the compensation of the owners affected by the agrarian reform in 1946.

Given that tourism law ${ }^{48}$ of 1993 was repealed by the $\mathrm{Law}^{49}$ of 2007, all the terms in means of it, were abolished. Such as "Incentive areas", "Incentive Person" and "Incentive Activity" were meaningless. The new challenge of the government and institutions was the regulation of the situations created on the field and not only. There were several issues to be solved such as:

- The future role of the "Incentive areas" approved by the law of 1993.

- The built and sell scheme

- The registration titles

- The ownership of land and buildings

The government decides to put these properties in civil circulation by removing so from the "dead capital" fund. This decision was concluded by approving the law no. 10186 in 2009.

As explained in the Law's Commission minutes, “... as long as it is not resolved ownership of the site, the building cannot be subject to civilian traffic as sale and purchase, as no institution gives property titles. To continue to allow this great national wealth to circulate outside state institutions?...”. Law's objective were:

- $\quad$ To end once and for generation the legal problem that produces both ownership of land and ownership of buildings constructed.

- Administration of real property in the areas of tourism development as a priority, the resolution of the ownership of land, taken as final and legal solution, after the abusive relationship ends located between subjects who developed the construction area and subject to purchased from this property.

- $\quad$ The new law "On the regulation of land ownership in the state tourism priority areas" is a successful attempt by the Government to resolve in a fair and accurate a distorted legal relationship that occurred in tourist areas.

Different efforts have been made by Albanian governments, in developing strategies on Tourism sector. In 2007, was created the first institution on monitoring and planning tourism strategies, National Agency on Tourism and the government in 2013 created the Coast National Agency. Objectives of activity of the Agency are: i) Ensure the conservation and sustainable development of the coastal zone; ii) Implementation policies and strategies for integrated management of the coastal zone; iii) Coordination of related programs in this area; iii) Promotion of investment in the area;

${ }^{48}$ Law no. 7501, dated 19.07.1991, "On land"

${ }^{49}$ Law no.9734, date 14.5.2007 "On Tourism" 
Book of Proceedings

International Conference on Architecture and Spatial Planning

\subsection{Conceptual framework}

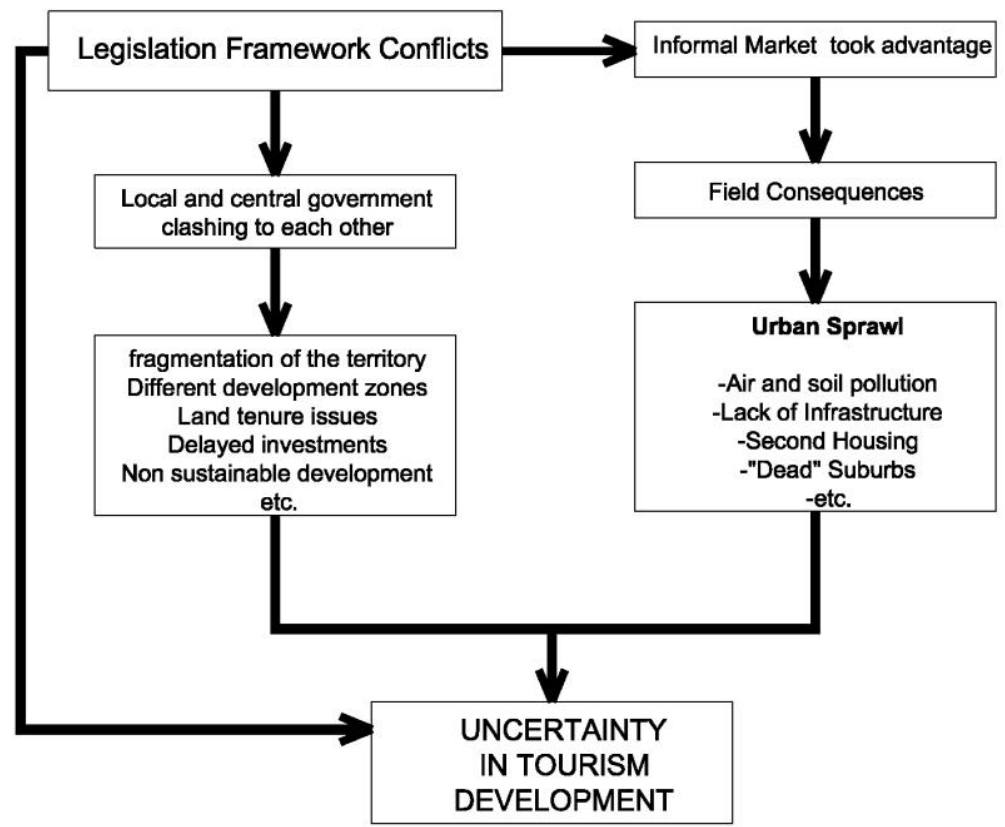

Fig.4 Conceptual framework

\section{Conclusions}

\section{Findings and Conclusion about the First Phase}

- Unclear issues on land ownership rights between former owners (the one expropriated at 1946) and new owners that benefited the land by the law "On land" in 1991.

- The fall into informal market of the owners of 7501, by selling and dividing land without legal documents.

- $\quad$ The law On the development of priority touristic zones, 1993 gave priority in developing tourism infrastructure along the coast, by stimulating the private initiative. Planning was left to private entrepreneurs who designed partial plans according to their interests, without having previously approved the tourism development strategy and spatial plan. 
Legislative framework conflicts and their impact in generating the phenomena of coastalization in Albania

\section{Findings and Conclusion about the Second Phase}

- $\quad$ None measurement were taken in legislation framework, neither instruments in monitoring or controlling the situation on field this lead to the development of the informal market on land ownership.

- Several initiatives by the local government were taken, in construction permits inside the tourism zones, even if there wasn't their competence.

- $\quad$ Lack of control of the territory has lead to aggravation and stimulation of the informal market in both land and construction in agricultural land but also inside the tourism destined areas.

- The initiative of approving a partial plan for Golem alongshore, resulted inappropriate, because it didn't clarify the tourism development zone from the urban one. Instead of these, the plan designed a mix use zone.

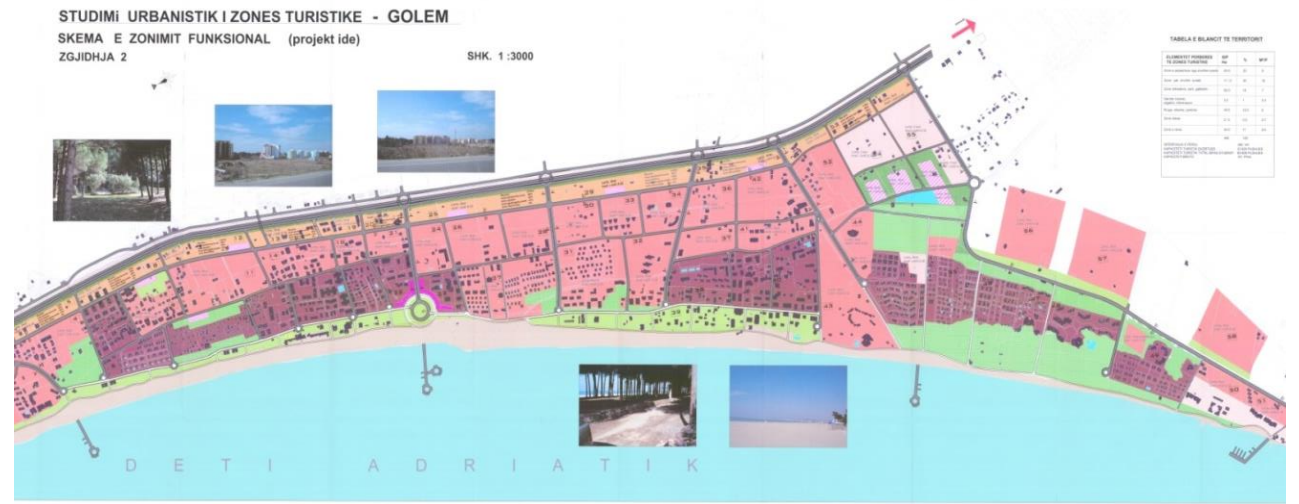

Fig.5 Urban Plan of priority tourism zone -Golem, 2004 Source: Tirana District Urban Plan Office 


\section{Book of Proceedings \\ International Conference on Architecture and Spatial Planning}
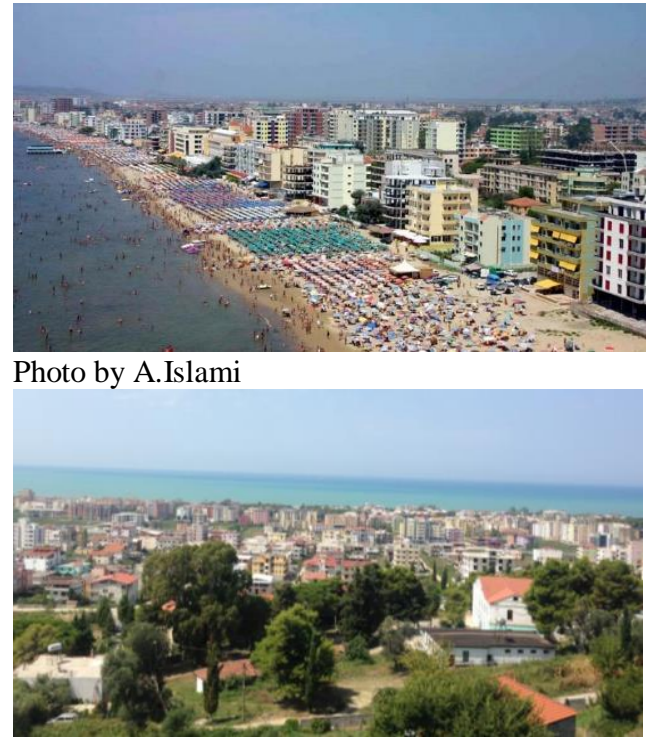

Photo by A.Islami

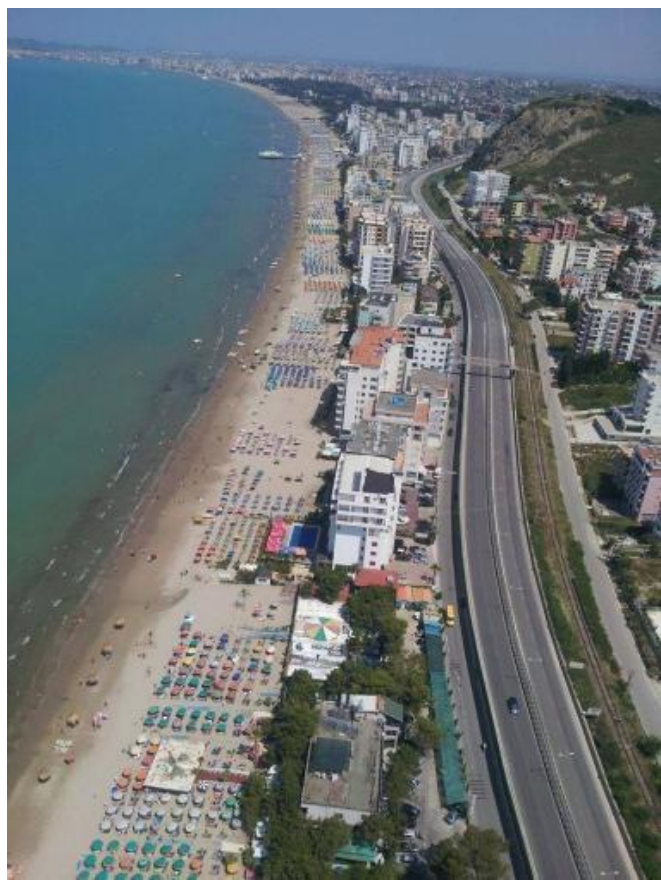

Photos by Author

Fig.6 Results on the field

\section{Findings and Conclusion about the Third Phase}

- Intervention in terms of the law 9482, 2006 on the informal market on land and buildings. Legalization instrument took place all over the country, by excluding tourism zones, as destined only for tourism purpose.

- The new law On Tourism, in 2007, abolished the one of 1993. Neither tourism structure nor incentive titles were given, in order to stop further aggravation of the informal market situation created on tourism priority zones.

- Implementation of the law 10186, on 2009, on the "Dead capital" inside tourism structures built under the law of 1993. Legalization of the structures and privatization of the land, took place. The transformation of the "tourism destined structures" into private property, consequently brought the development of new urban zones.

- Urban Plan of priority tourism zone at Golem area, took into consideration the fact that the area is populated and so to be treated as an urban area. 
Legislative framework conflicts and their impact in generating the phenomena of coastalization in Albania

\section{Conclusion about the three hases}

The three phase on which legislation framework has passed through, has one common denominator:

The impact on the field in terms of urban sprawl that in coastal area generate the phenomenon of coastalization.

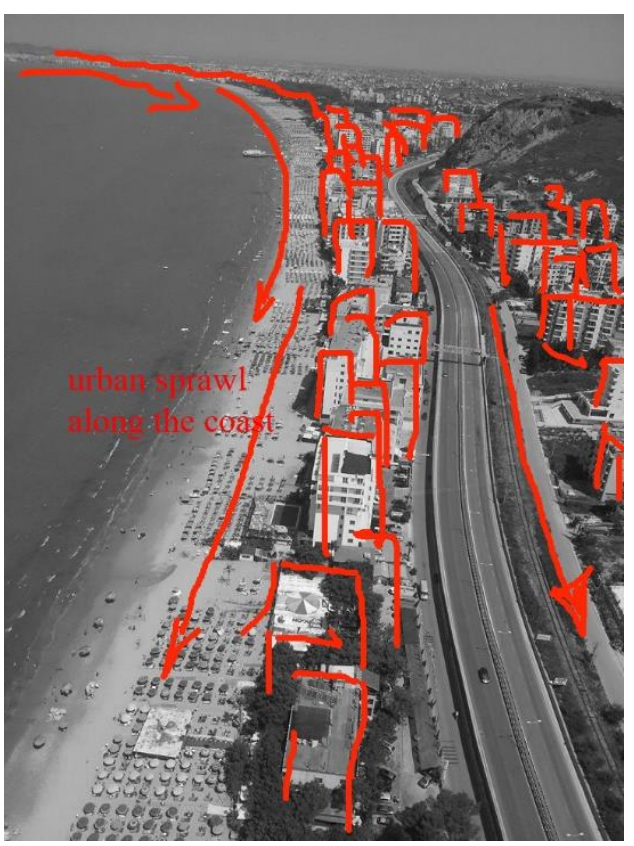

\section{Refernces:}

1. ALIKO, H. SHERKO, R. (2002) On regularization of informal settlements in Albania [Tirana, Albania : s.n.], 2002. 22 p.

2. ANDONI, D. (2007) The paradigm of legalization - a paradox or the logic of development. Conference: The need for modern Estate Cadastre and Spatial Planning, Sounio, Greece, 28-31 March.

3. ANDONI, D. (2007) Legalization of informal settlements in Albania. Paper presented at the 5th Regional Vienna Declaration Review Meeting, Stability Pact for South Eastern Europe, 22-23 October, Vienna, Austria. Typescript.

4. BERTAUD, A. (2006) Urban development in Albania: the success story of the informal sector. Typescript

5. DE SOTO, H. (2003) The mystery of capital: Why capitalism triumphs in the West and fails elsewhere. Tirane, Aferdita .

6. Document of the World Bank (2009) Albania Building Competitiveness in Albania Volume II Sector Case Studies: Apparel and Footwear, Tourism, Mining. Europe and Central Asia Region. Report No. 47866-AL 
Book of Proceedings

International Conference on Architecture and Spatial Planning

7. LUSHO, SH. PAPA, DH. (1998) Land fragmentation and consolidation in Albania. Madison, Wis.: Land Tenure Center, University of Wisconsin-Madison, 1998. 39 p. (Working paper, no. 25. Albania series) http://www.wisc.edu/ltc/wp25

8. Vienna Declaration (2004) Annex B: Vienna Declaration. In Ministerial Conference on Informal Settlements in South Eastern Europe, Vienna, 28 Sep - 01 Oct 2004. (Retrieved on October 25th, 2007 from http://www.stabilitypact.org/humi/041001-conference.html 